\title{
Allaying the Fears Metaphorically: Representation of Coronavirus Crisis in Saudi English Newspapers
}

\author{
Abdulrahman Alsaedi ${ }^{1}$ \\ ${ }^{1} \mathrm{PhD}$ Candidate, School of Media, Arts and Humanities, University of Sussex, Brighton, UK \\ Correspondence: Abdulrahman Alsaedi, School of Media, Arts and Humanities, University of Sussex, Flat 181F, \\ Northfield Lane, Falmer, Brighton, BN1 9BJ, UK. E-mail: afturki7@hotmail.com
}

Received: December 20, $2020 \quad$ Accepted: January 21, $2021 \quad$ Online Published: January 26, 2021

doi:10.5539/ijel.v11n2p91 URL: https://doi.org/10.5539/ijel.v11n2p91

\begin{abstract}
The present study is an analysis of the representation of the crises brought about by the coronavirus disease (Covid-19) at the socio-economic front in Saudi Arabia and the world over, in two Saudi English dailies, Saudi Gazette and Arab News. The study analyses the use of metaphors in the language employed in reporting the news items or presentation of expert opinions on the virus and the disease, and the deeper significance of the use of such metaphors in writing on the pandemic and its causes. Cognitive Metaphor Theory (CMT) has been employed as framework of analysis and the data have been analysed using Pragglejaz Group's MIP. Six news and opinionated items (two from Saudi Gazette and four from Arab News) have been analysed. The analysis shows that the crisis writing relies heavily on war metaphors, Sinophobia metaphors, and metaphors allaying fears. The metaphorical language used in the selected English dailies plays a big role in allaying the public fears on the spread of the disease and putting the government programs in the right perspective. The use of metaphorical language to talk about the pandemic and its potent causes has been quite effective in addressing the sensitive issues since human psyche displays deep-set prejudices against certain panic conditions and social formations.
\end{abstract}

Keywords: Covid-19, news reporting, metaphors in discourse, Saudi English dailies, MIP, allaying fears

\section{Introduction}

\subsection{The Research Background}

Ever since a new strain of SARS - (Severe Acute Respiratory Syndrome) like virus was identified in November 2019 in Wuhan, China, causing acute respiratory syndrome leading to most patients' death, there has been a continuous stream, or rather overflow, of information on the deadly virus, called SARS-CoV-2 (SARS Coronavirus-2), and the disease caused by the virus as Covid-19 (Coronavirus Disease-19), in print as well as visual media. The virus has proved to be highly contagious, spread worldwide in a short span of time and caused a large number of fatalities (see Appendix B for total number of infections and fatalities in countries affected in a major way, as of 24 September 2020), to be recognized as a pandemic by WHO (World Health Organization. WHO announced COVID-19 outbreak as a pandemic on 11 March 2020). Since the contagion spread so fast and the fatalities have been so high, it became essential for respective state governments to take measures to stop, or at least contain the spread, keeping in mind their own health systems and economic capabilities. But, under the given circumstances, in the prevalence of so many [conspiracy] theories running amuck among the public (Alper et al., 2020; Miller, 2020), and information and misinformation freely available to the public at large in the age of the Internet, it also became imperative for state governments to provide authentic information to people. Print media play a big role in putting the things in the right perspective, and the language used in print essentially becomes the message since human language codes events of cultural significance as messages (see Gerbner, 1985). Media, in general, not only shapes public opinion but also shapes public discourse (Cukier et al., 2009). Moreover, since media discourse draws largely on shared knowledge (O'Keeffe, 2006), it is pertinent to investigate how media discourse makes use of metaphorical language, which also draws on shared knowledge. Use of metaphorical language bears its own significance in such an atmosphere. The current research has its genesis in the academic curiosity to study the language, especially the use of metaphors, employed in Saudi English dailies in reporting Covid-19 crisis in Saudi Arabia and the world over. 


\subsection{The Research Problem}

In view of the growing public fears over their physical, mental and economic well-being as represented in Saudi media, and the growing hate campaign in the media globally against the Chinese and many other Asian nationalities, which is fueled by the news that the Covid-19 virus was manufactured in a Chinese lab and leaked due to their negligence, it became imperative to study the news discourse on the virus in the Saudi print media. The English dailies published in Saudi Arabia carry articles not only by Arab writers but also by writers from English speaking countries, therefore, the researcher determined to carry out a study on the news discourse in the two English dailies.

\subsection{Research Objectives}

The current research was primarily aimed at investigating the significance of the use of metaphors in reporting the Covid-19 crisis in selected English newspapers in Saudi Arabia. The secondary objective of the study was to investigate what orientation the news or the opinionated articles would take as regards forming a public opinion towards the pandemic and its causes, impregnated with the intended metaphors.

\subsection{Research Questions}

The current research was designed to find answers to the following research questions:

RQ1: How is the crisis caused by Covid-19 pandemic presented in metaphors used in newspaper discourse in selected Saudi Arabian English dailies?

RQ2: What orientation did the news write-ups/opinionated articles take with the use of metaphors in the language they were couched in?

\section{Related Literature}

The import of the metaphors employed in the news write-ups/articles selected for the current research has been investigated through the lens of conceptual/cognitive metaphor theory (CMT) propounded by Lakoff and Johnson (1980a), while to identify the metaphors in the corpus the metaphor identification process (MIP) designed by Pragglejaz Group (2007) has been employed. We shall discuss the key points of the theory and the process. We shall also discuss the previous research studies related to the current topic of research in the following sub-sections.

\subsection{Cognitive Metaphor Theory}

Prior to the advent of CMT, the views on metaphors prevalent in the literary circles was that metaphors are literary devices used for figurative embellishment. In the latter half of the twentieth century, interventions from theories in linguistics brought about a shift in the idea of metaphors in human language since contemporary linguistics rejected the notions that metaphor is a special use of language, and propagated the view that human cognition, and hence human language, is largely figurative (Johnson, 1987; Lakoff, 1987; Lakoff \& Johnson, 1980; Sweetser, 1990; Turner, 1987). Cognitive theory of metaphor, under the influence of the linguistic turn in literature, in a major shift, makes an attempt to understand one idea (literal sense) in terms of another (figurative sense). For example, quantity (more/less) may be understood in terms of directionality (up/down). Lakoff and Johnson shifted the paradigm by arguing that metaphors are not literary devices but elements of human cognition since most of human cognitive understanding- scientific, mathematical, philosophical, religious, social, political, economic, and so on - is built upon them; they help us cognize the world phenomena. We have cognition of the world in terms of cognitive metaphors. According to Lakoff and Johnson (1980a), conceptual metaphors are cross-domain (source domain/target domain) mappings that structure our thought on phenomena. Let's take an example from Lakoff and Johnson (1980a): 'Argument is War' is a conceptual metaphor since we conceptualise argument as a fight, so, whatever is involved in a fight, such as winning, losing, defeat, defence, attack, shooting, bringing down, strength, weakness, and so on, is understood to be involved in argument as well. Thus, we have such linguistic expressions as 'winning an argument,' 'losing the case,' 'couldn't defend his/her point,' 'shot down the opponent's argument,' 'attacked the adversary's point,' 'a weak case,' 'a strong case,' etc. All these are examples of linguistic realizations (linguistic metaphors) of the overarching conceptual metaphor 'Argument is war.' Falck (2012, p. 110), observes that, "even though metaphors are grounded in embodied experience, our language still shapes how these experiences are used".

Even the more directly apprehensible experiences are also largely understood through imaginative thinking, based on image-schema (Johnson, 1987). Image-schema are preconceptual structures preserved in human brain as mental images, acquired through our bodily experiences. The imaginative cognitive mechanism exploited to grasp the abstract reality undergoes two different but related processes: One in which "one experiential domain is 
partially "mapped" or projected, onto a different experiential domain, so that the second domain is partially understood in terms of the first one" (Barcelona \& Valenzuela, 2011, p. 13). The product of this process is called a 'metaphor.' The mapped domain is termed as the source domain, while the domain onto which the source domain is mapped is termed as target domain. The other process of cognitive mechanism involves partial grasping of "one experiential domain in terms of another experiential domain included in the same common experiential domain" (Barcelona \& Valenzuela, 2011, p. 14). The product of this process is called 'metonymy.' The target domain in metonymy is highlighted or mentally activated, but with a limited discourse purpose (Lakoff, 1987, chap. 5). According to Lakoff (1987, p. 77), "Metonymy is one of the basic characteristics of cognition. It is extremely common for people to take one well-understood or easy-to-perceive aspect of something and use it to stand either for the thing as a whole or for some other aspect or part of it".

CMT has been subjected to some criticism too, especially its idea, and claim, of immediacy between conceptual metaphors and first-hand experience. Madsen (2016, p. 881), for instance, problematizes the grounding of conceptual metaphors in first-hand experience arguing that "the hypothesis contains some conceptual ambiguities and empirical difficulties". But, as regards our purpose, we shall not take the criticism into consideration and believe in the immediacy between metaphors and experience.

\subsection{Pragglejaz Group and MIP}

The Pragglejaz Group has developed a method to identify metaphorically used words in discourse. The tool can be applied to many research contexts. The first step in the identification process is to read the text in question for a general understanding of the meaning of the text and to determine the lexical units in its discourse. The second step is to establish the contextual meaning of the determined lexical units, while the third step is to determine whether the lexical units have more basic contemporary meanings in contexts other than the present context. And the final step is to see if the lexical units have more basic meanings in current-contemporary contexts, and to decide whether the contextual meanings stand in contrast to the basic meanings but are understood in comparison with them. If that is the case, the given lexical units are metaphorical.

The Pragglejaz Group method can be demonstrated taking the following example sentence from the newspaper article selected for the current study:

The Lancet, the world's leading medical journal, praised the efforts of Saudi Arabia in confronting the coronavirus pandemic. ("Top medical journal lauds Saudi Arabia", 2020)

The sentence is divided into lexical units, followed by determining their (i) contextual meanings, (ii) basic meanings, and (iii) contextual versus basic meanings, and then arriving at the decision whether the lexical meanings are metaphorically used or not.

/The / Lancet /, the /world's / leading /medical / journal /, praised / the / efforts / of / Saudi Arabia / in / confronting / the /coronavirus / pandemic/.

This step is followed by determining the contextual and basic meanings of the units and then establishing a contrast between them. The final step is reporting the result. For instance, the results obtained from the analysis of the given sentence are as following:

$\begin{array}{ll}\text { Lexical Unit } & \text { Metaphorically used? } \\ \text { The } & \text { No } \\ \text { Lancet, } & \text { No } \\ \text { the } & \text { No } \\ \text { world's } & \text { No } \\ \text { leading } & \text { Yes } \\ \text { medical } & \text { No } \\ \text { journal, } & \text { No } \\ \text { praised } & \text { No } \\ \text { the } & \text { No } \\ \text { efforts } & \text { No } \\ \text { of } & \text { No } \\ \text { Saudi Arabia } & \text { No }\end{array}$




$\begin{array}{ll}\text { in } & \text { No } \\ \text { confronting } & \text { Yes } \\ \text { the } & \text { No } \\ \text { coronavirus } & \text { No } \\ \text { pandemic } & \text { No }\end{array}$

\subsection{The Significance of News Discourse}

News discourse is a genre of writing that moves beyond the confines of particularised media texts, such as creative fiction, creative non-fiction, other non-fictional genres, and so on, and operates in socio-economic-political and cultural practices. Therefore, this genre of writing is very important for analysis, to understand the metaphorical use of language beyond the common spheres of metaphorical usage. And that is also the reason why the conceptual metaphor theory is so relevant for this study.

News discourse is meant for a specific communicative purpose for/in a specific discourse community. It is important that the specific purpose of the news discourse is analysed for further understanding of the community and its linguistic practices. News discourse is pregnant with the potentials of being multi-semiotic (Bednarek \& Caple, 2012; Molek-Kozakowska, 2014), which means that it is not "restricted to the semiotic system of language alone but, crucially, also incorporating the semiotic system of images" (Bednarek \& Caple, 2012, p. 2), and therefore, news discourse is also a multi-semiotic genre of writing. For our purpose, analysis of news discourse is important since metaphoricity is yet another semiotic system, apart from visual and other types of images prevalent in the news media. Moreover, research studies on media discourse highlight the significance of message as culturally significant events in the media are coded as messages (Gerbner, 1985), the power of news media to shape public opinion and discourse (Cukier et al., 2009), and the use of shared knowledge in the news media (O'Keeffe, 2006), to draw the point home.

Bednarek and Caple (2012, p. 6) list three major reasons for the study of news discourse. They are: "(1) there is a lot of it; (2) it is easy to collect examples of it; and (3) most importantly, since we all spend a lot of our time consuming it, it has great potential to exert considerable influence over us".

Emphasizing the importance of the study of news discourse, Bednarek and Caple (2012, p. 6) add that "Sometimes we may modify our behaviour, ideas and beliefs, based on what we have read or heard and in this way we navigate our paths through our lives as members of a particular social group. This also points to the power of the media: the influence they exert both on our governments and major institutions as well as their ability to shape our ideas and behaviours". The point is quite significant from the perspective of the current study as well since the use of metaphorical language in news discourse adds one more dimension to the influencing factors of the media upon people's ideas, decisions and behaviours. For our purpose, that is, to study news discourse from the perspective of the use of metaphors in newspaper, the importance of news discourse lies in the abundant use of metaphors in news discourse.

As discussed above, Cognitive Metaphor Theory is particularly suitable for the analysis of news discourse since news discourse makes frequent use of metaphorical language, and metaphorical usage in a genre of writing different from literary/creative writing brings forth useful insights.

\subsection{Literature Review}

The socio-economic crisis caused by Covid-19 pandemic is a comparatively recent phenomenon, therefore, there does not exist any significant research work/literature on the topics related to the crisis caused by the pandemic, such as its socio-economic and political impacts, or the deeper significance of the language/metaphors employed to paint the picture of the crisis, whether in Saudi Arabia (see, Al-Thaqafi, 2020; Jdaitawi, Jdaitawi, \& Alkurdi, 2020; Memish, Aljerian, \& Ebrahim, 2020) or around the world. At present the widespread feeling among writers/researchers is that in news reporting, the most common images are the Chinese origin of the virus and the pandemic as a war, both of which generate negative feelings among the general public (Freedman, 2020; Rafi, 2020; Yan et al., 2020). The one is the cause of Sinophobia, while the other causes extreme fears. That explains why the few research studies that are carried out on the issue are largely motivated to explore these two points. For example, Rafi (2020) notes that newspaper reporting of coronavirus in general is more of a discourse centred around fear, specially of Sinophobia. The researcher says that the language used to report about COVID-19 in the newspaper, such as The New York Times perpetuates the discourse of fear and eventually raises anti-Chinese sentiments. The infection has promoted bizarre linguistic forms about the public sphere and social life that generates the discourse of fear. Freedman (2020), on the other hand, finds the echo of war metaphor in the 
discourse on Coronavirus in newspapers. Freedman proves his point by pointing out the frequent use of metaphors, such as "front line workers, "at risk," scientists endeavour to find a vaccine to "repel" the "invading pathogen," Government ministers meet in virtual "war cabinets," ordinary folk volunteer to do "their bit," and so on. The author says that "It may not always be wise to invoke wars when confronting pandemics, but there are legitimate comparisons that go well beyond rhetorical devices to spur on the national effort" (no page numbers).

The virus has devastated the world economy in general as it has severely restricted the movement of people, and the economy of oil-dependent Middle Eastern nations in particular. Arezki and Nguyen (2020), in an essay published in an edited book point out that coronavirus hurts the Middle East and North Africa through many channels, especially effecting the Oil prices, value chain, tourism and travel in the MENA region. Yet, despite the unsettling economic losses, the Kingdom of Saudi Arabia has put in place an efficient system of prevention and control as researchers, such as Ahmad, Alkharfy, Alrabiah and Alhossan (2020), Alshammari, Altebainawi and Alenzi (2020), Al-Thaqafi (2020), Jdaitawi et al. (2020), and Memish et al. (2020) in their studies laud Saudi Arabia's early precautionary actions in an effort to contain the spread of COVID-19 in the Kingdom. Jdaitawi et al. (2020, p. 1), for example, note that "Saudi Arabia is one of those countries that made sustainable efforts to strengthen their capacities to detect and control such emergencies". Saudi Arabia took a serious note of the coronavirus after the first confirmed case was reported on March 2 (see, for instance, "Al-Rajhi Rallies Support", 2020; "In Numbers", 2020; "Outing Corona Test Results", 2020). Several critical decisions were announced in the Kingdom to detect and control the COVID-19, such as isolation and quarantine, temperature screen measures, closing the borders, suspending local and international flights, and so on. "Furthermore," note the researchers, "Saudi Arabia has adopted great efforts and several clinical and other strategies to control COVID-19 which can be divided into surveillance and containment measures".

\section{Methodology}

\subsection{Research Design}

The current research is a corpus-based study. Articles sourced from two Saudi English dailies formed the small corpus material used for the analysis of metaphorical usage in journalistic writing. The majority of writers of the articles sourced for the study hail from Saudi Arabia, while a few of them, whose opinions have been sourced by the papers, are based abroad. The current study was designed as a combination of quantitative and qualitative analysis. The individual lexical units were mainly excerpted from the selected texts in a quantitative search using Pragglejaz Group MIP technique. The sentence from the texts were divided into lexical units, followed by determining their (i) contextual meanings, (ii) basic meanings, and (iii) contextual versus basic meanings. The final step was to determine whether the lexical meanings were metaphorically used or not. In addition, meanings of multiword units were subjected to contextual and co-textual interpretive exercise. The socio-political import of the excerpted metaphors was evaluated using qualitative interpretive method.

\subsection{Sources of Data Collection}

The data for the current study have been sourced from Saudi Gazette and Arab News, the two English dailies published from Saudi Arabia. Saudi Gazette started publication in Saudi Arabia in 1976 while the Arab News, the biggest daily in Saudi Arabia, in 1975. For the present study, only six news/opinionated items have been selected for analysis, for two reasons. First, since the Covid-19 is a recent phenomenon, not much has been written yet on the crisis in Saudi Arabian context. Second, out of the available writings too, the researcher could find only the selected ones dense with metaphor use as the focus of the present study was on the analysis of metaphors. Consequently, in Saudi Gazette only two articles were found suitable for the purpose, while four write-ups were found suitable in Arab News.

\section{Results: Discussion}

Six news items and opinionated articles were analysed for the current study for metaphor use in their language. Using Pragglejaz Group MIP to identify metaphoricity in individual lexical units, and contextual as well as co-textual measures for the multiword units, a total of 125 lexical items were identified with instances of figurative potentials (image schemata, metaphoricity, blending, metonymic expression) in their given contexts (see Appendix C). It is to be noted at this juncture that since my focus in the study was on pandemic crisis metaphors, I did not take into account all the instances of metaphors that several other lexical units/multiword units would have instantiated since a whole range of phraseological combinations are capable of transpiring metaphorical and figurative interpretations.

\subsection{War Metaphors}

It is obvious from the daily news stories we come across since the spread of the Covid-19, that the situation is 
viewed in general as a war situation, and therefore, it's no surprise that the news discourse and opinion articles in the selected newspapers also rely on war metaphors to describe the prevailing atmosphere in Saudi Arabia. Some of the most common metaphorical expressions in the news stories and articles stylistically derive from the cognitive choice for mapping the embodied physical as well as mental/imagined experience of wars, such as combat, raging, toll, emergency, front line, high-risk, critical condition, fight the pandemic, etc. (see, for example, Al-Khudair, 2020) onto the abstract social reality brought about by the coronavirus, such as large-scale fatalities, physical suffering, incapacitating physical conditions, devastating economic destruction, and so on.

Such a mapping is a useful device to present an unprecedented and complex social situation in terms of a known and experienced spatial schema arrangement. For example, the following excerpts from a selected news story ("Top medical journal lauds Saudi Arabia", 2020) draws on the known/imagined experiences of war and military combat:

(1) The Lancet, the world's leading medical journal, praised the efforts of Saudi Arabia in confronting the coronavirus pandemic. In an article titled "COIVD-19: the worst may be yet to come," the journal noted that Saudi Arabia has allocated an unlimited budget, raised the capacity of intensive care units, and opened hundreds of so-called "fever clinics" (Tatman clinics) to ensure free access to all patients who have symptoms of the virus.

The war metaphor confronting maps out the cognitive parallels between facing the enemy in a war zone and facing the virus all around since in both the cases there is a risk to life. The experiential domain of injury in wars, a bodily experience (source domain), constituting the image-schema here, is partially mapped and projected onto the risk of injury/death, a potential eventuality associated with coronavirus (target domain) infection.

\subsection{Metaphors Used in the Context of Sinophobia}

The first instances of coronavirus were noted in Wuhan, a town in China. The further news stories followed the world over were that the origins of the deadly virus lay in a wildlife market in Wuhan, and the human contraction took place from bat-flesh consumed in China. This theory everywhere led to a widespread hate campaign against the people of Chinese descent. The opinionated article published in the Arab News (Doyle, 2020) uses words, such as 'stemming,' 'verbal attacks,' 'racist antipathy,' 'global conspiracy,' 'disease manufactured,' etc. as metaphors to indicate Sinophobia. But the writers refer to the situation in London and New York, not in Saudi Arabia. For instance, look at the following excerpt from the article:

(2) This also includes not committing coronavirus hate crimes. Many expat Chinese communities have reported physical and verbal attacks. Typically, these attacks are spreading to anyone who looks Asian. Chinatowns in major cities such as London and New York have reported a sharp drop in visitors. Some of these are not just motivated by raw fear of a virus, but also latent racist antipathy toward Chinese and Asians.

\subsection{Metaphors Allaying Public Fears}

As we have discussed above, the coronavirus has caused widespread social and economic destruction worldwide. Therefore, it's but natural for a common man to be concerned for his/her social and economic well-being. The news discourse in the selected English dailies reflect the efforts of Saudi government to lay the public fears to rest, through the use of metaphors, such as 'lauds,' 'unlimited budget,' 'devoted,' 'to fuel the recovery,' and so on. For instance, the insecurity in the private sector caused by financial instability, an extremely complex situation, is easy to grasp presented through a known and experienced spatial schema arrangement, in the metaphor 'to fuel the recovery.' The metaphor maps the common experience of fuel keeping a needed fire/engine going onto the target domain of keeping the economic engine going as the government promises to supply enough funds. Similar is the case for the health sector as reported in the following lines (Kane, 2020):

(3) Since those early days, the Kingdom has more fully grasped the reality of the pandemic's fallout, with multibillion-riyal packages devoted to private sector support and vital financial input for the health sector. These commitments bring the Kingdom more in line with the level of fiscal support pledged by other G20 members.

\subsection{Other Metaphors}

Apart from the war, Sinophobia and allaying the public fears metaphors, the news discourse in the selected papers employ several other metaphors, such as 'debt,' 'repay,' 'spike,' 'heading downward,' and so on, that help the readers grasp a complex situation in terms of everyday experiences. For instance, look at the excerpt from a selected article (Kane, 2020): 
(4) In layman's terms, that means nobody has much of a clue where the global economy is heading - except that it is downward. The International Monetary Fund last week put the official seal on it, forecasting a global contraction of 3 percent. That makes a near 6 percent downward swing over 12 months, the biggest decline since the Great Depression of the 1930s.

'Heading downward' is a bodily experience which is mapped onto the situation of a country performing badly in economic terms.

For easy readability, the findings can be summarized as in Table 1 given below:

Table 1. Summary of findings

\begin{tabular}{|c|c|c|c|}
\hline War n & Sinophobia metaphors & Metaphors allaying public fears & Other metaphors \\
\hline $\begin{array}{l}\text { Some of the most common } \\
\text { metaphorical expressions in the } \\
\text { news stories derive from the } \\
\text { cognitive choice for mapping } \\
\text { the embodied physical and } \\
\text { mental experience of wars, such } \\
\text { as combat, raging, toll, } \\
\text { emergency, front line, high-risk, } \\
\text { critical condition, fight the } \\
\text { pandemic, etc. }\end{array}$ & $\begin{array}{l}\text { Since the first instances of } \\
\text { coronavirus were noted in } \\
\text { Wuhan, in China, there is a } \\
\text { wide-spread sentiment of hate in } \\
\text { the media against the Chinese, } \\
\text { and therefore, news discourse is } \\
\text { rife with Sinophobia metaphors, } \\
\text { such as verbal attacks, racist } \\
\text { antipathy, global conspiracy, } \\
\text { disease manufactured, etc. }\end{array}$ & $\begin{array}{l}\text { The metaphors in the language used } \\
\text { in the news discourse in Saudi } \\
\text { Arabia reflects the efforts of Saudi } \\
\text { government to lay the public fears to } \\
\text { rest, such as lauds, unlimited budget, } \\
\text { devoted, vital, resist the temptation } \\
\text { to overdramatize, and so on. }\end{array}$ & $\begin{array}{l}\text { The other metaphors } \\
\text { used in the news } \\
\text { discourse on the crisis } \\
\text { help readers grasp a } \\
\text { complex situation in } \\
\text { terms of everyday } \\
\text { experiences, such as } \\
\text { debt, repay, warned about } \\
\text { a spike, pessimists, etc. }\end{array}$ \\
\hline
\end{tabular}

\section{Conclusion}

To sum up, metaphors are exemplification of one property in terms of other property. The property that is exemplified is usually abstract in nature, therefore, cognitively complex to grasp, while the property used in exemplification is concrete, generally bodily experience or other known situation, and which pre-exists the other, as mental experience providing the structural image-schema. The language employed in the news discourse and the opinion articles excerpted from the two Saudi English dailies, Saudi Gazette and Arabs News, rely on this property of metaphors to reflect, and in turn build, a positive environment in Saudi Arabia in the face of a pandemic that has otherwise crippled, not only world economy and health systems, but also people's mental strength and polarized the world in socio-political terms. The selected Saudi English dailies are critical of the general media campaign against the Chinese and other Asian nationalities and stay away from spreading Sinophobia. Though in line with others, they also employ war metaphors and other metaphors commonly found used in the crisis coverage, such a usage at times seems essential to highlights the dangers of the crisis as well as the government efforts to contain it.

\section{Suggestions for Further Research}

The Covid-19 crisis is still going on, and further research on how the latest developments are portrayed in the news media is urgently needed. Apart from the English dailies, discourse researchers in Saudi Arabia can investigate the use of metaphorical language in Arabic dailies as well. One of the topic areas can be the metaphorical depiction of the atmosphere in the Kingdom after the arrival of Covid-19 vaccine.

\section{References}

Ahmad, A., Alkharfy, K. M., Alrabiah, Z., \& Alhossan, A. (2020). Saudi Arabia, pharmacists and COVID-19 pandemic. Journal of Pharmaceutical Policy and Practice, 13, 41. https://doi.org/10.1186/s40545-020-00243-1

Al-Khudair, D. (2020, April 20). COVID-19 cases in Saudi Arabia surpass 10,000. Arab News. Retrieved from https://arab.news/w66ce

Al-Rajhi rallies support for youth hit by COVID-19 in G20 ministerial meeting. (2020, September 10). Saudi Gazette. Retrieved from https://saudigazette.com.sa/article/597802

Al-Thaqafi, T. (2020, March 10). Saudi Arabia gets to grips with coronavirus. Arab News. Retrieved from https://arab.news/ghf2g

Alper, S., Bayrak, F., \& Yilmaz, O. (2020). Psychological correlates of COVID-19 conspiracy beliefs and preventive measures: Evidence from Turkey. Current Psychology. https://doi.org/10.1007/s12144-020-00903-0 
Alshammari, T. M., Altebainawi, A. F., \& Alenzi, K. A. (2020). Importance of early precautionary actions in avoiding the spread of COVID-19: Saudi Arabia as an Example. Saudi Pharmaceutical Journal, 28(7), 898-902. https://doi.org/10.1016/j.jsps.2020.05.005

Arezki, R., \& Nguyen, H. (2020). Novel coronavirus hurts the Middle East and North Africa through many channels. In R. Baldwin \& B. Mauro (Eds.), Economics in the Time of COVID-19 (pp. 53-58). [e-book] Retrieved from https://cepr.org/sites/default/files/news/COVID-19.pdf

Barcelona, A., \& Valenzuela, J. (2011). An Overview of Cognitive Linguistics. In M. Brdar, S. T. Gries \& M. Ž. Fuchs (Eds.), Cognitive Linguistics: Convergence and Expansion (pp. 17-44). Amsterdam: John Benjamins. https://doi.org/10.1075/hcp.32.05bar

Bednarek, M., \& Caple, H. (2012). News Discourse. London and New York: Continuum International Publishing Group.

Cukier, W., Ngwenyama, O., Bauer, R., \& Middleton, C. (2009). A critical analysis of media discourse on information technology: Preliminary results of a proposed method for critical discourse analysis. Information Systems Journal, 19(2), 175-196. https://doi.org/10.1111/j.1365-2575.2008.00296.x

Doyle, C. (2020, March 02). We have to make sacrifices to halt coronavirus spread. Arab News. Retrieved from https://arab.news/yct5z

Falck, M. J. (2012). Metaphor variation across L1 and L2 speakers of English: Do differences at the level of linguistic metaphor matter? In F. MacArthur, J. L. Oncins-Martínez, M. Sánchezgarcía \& A. M. Piquer-Píriz (Eds.), Metaphor in Use: Context, culture and communication (pp. 109-134). Amsterdam: John Benjamíns. https://doi.org/10.1075/hcp.38.10joh

Freedman, L. (2020, April 11). Coronavirus and the language of war. New Statesman. Retrieved from https://www.newstatesman.com/science-tech/2020/04/coronavirus-and-language-war

Gerbner, G. (1985). Mass Media Discourse: Message System Analysis as a Component of Cultural Indicators. In T. A. van Dijk (Ed.), Discourse and Communication (pp. 13-25). Berlin: Walter de Gruyter.

In numbers ... how did the kingdom move to besiege the Coronavirus? (2020, March 20). AJEL. Retrieved from https://ajel.sa/Y2WTdw/

Jdaitawi, M., Jdaitawi, L., \& Alkurdi, R. (2020). Analyzing the Spread of COVID-19 in Saudi Arabia and Controlling Disease Strategies. International Journal of Internal and Emergency Medicine, 3(1), 1028. Retrieved from http://www.remedypublications.com/open-access/analyzing-the-spread-of-covid-19-in-saudi-arabia-and-con trolling-6014.pdf

Johnson, M. (1987). The body in the mind: The bodily basis of meaning, imagination, and reason. Chicago: University of Chicago Press. https://doi.org/10.7208/chicago/9780226177847.001.0001

Kane, F. (2020, April 21). Pandemic brings Saudi Arabia's 'whatever it takes' moment. Arab News. Retrieved from https://arab.news/b7v77

Lakoff, G. (1987). Women, Fire and Dangerous Things: What Categories Reveal about the Mind. Chicago: University of Chicago Press. https://doi.org/10.7208/chicago/9780226471013.001.0001

Lakoff, G., \& Johnson, M. (1980a). Metaphors We Live By. Chicago: The University of Chicago Press.

Lakoff, G., \& Johnson, M. (1980b). The Metaphorical Structure of the Human Conceptual System. Cognitive Science, 4, 195-208. https://doi.org/10.1207/s15516709cog0402_4

Madsen, M. W. (2016). Cognitive Metaphor Theory and the Metaphysics of Immediacy. Cognitive Science, 40(4), 881-908. https://doi.org/10.1111/cogs.12320

Memish, Z. A., Aljerian, N., \& Ebrahim, S. H. (2020). Tale of three seeding patterns of SARS-CoV-2 in Saudi Arabia. The Lancet. https://doi.org/10.1016/S1473-3099(20)30425-4

Miller, J. M. (2020). Do COVID-19 Conspiracy Theory Beliefs Form a Monological Belief System? Canadian Journal of Political Science, 53(2), 319-326. https://doi.org/10.1017/S0008423920000517

Molek-Kozakowska, K. (2014). Coercive Metaphors in News Headlines: A Cognitive-Pragmatic Approach. Brno Studies in English, 40(1): 149-173. https://doi.org/10.5817/BSE2014-1-8
O'Keeffe,
A. (2006).
Investigating
Media
Discourse. $\quad$ London:
Routledge. https://doi.org/10.4324/9780203015704 
Pragglejaz Group. (2007). MIP: A Method for Identifying Metaphorically Used Words in Discourse. Metaphor and Symbol, 22(1), 1-39. https://doi.org/10.1080/10926480709336752

Rafi, M. S. (2020). Language of Covid-19: Discourse of Fear and Sinophobia. Social Sciences and Humanities Open. https://doi.org/10.2139/ssrn.3603922

Saudi Gazette. (2020, July 22). Top medical journal lauds Saudi Arabia's efforts in combating COVID-19. Retrieved from https://saudigazette.com.sa/article/595823

Saudi Gazette. (2020, September 16). Outing corona test results: KSA second in G20 states. Retrieved from https://saudigazette.com.sa/article/598041/SAUDI-ARABIA/Outing-corona-test-results-KSA-second-in-G2 0 -states? ref=rss\& format=simple \&link=link

Sweetser, E. (1990). From etymology to pragmatics: Metaphorical and cultural aspects of semantic structure. Cambridge: Cambridge University Press. https://doi.org/10.1017/CBO9780511620904

Turner, M. (1987). Death is the mother of beauty: Mind, metaphor, criticism. Chicago: University of Chicago Press.

Yan, Y., Shin, W. I., Pang, Y. X., Meng, Y., Lai, J., You, C., .. Pang, C. H. (2020). The first 75 days of novel coronavirus (SARS-CoV-2) outbreak: recent advances, prevention, and treatment. Int. J. Environ. Res. Public Health, 17(7), 2323. https://doi.org/10.3390/ijerph17072323

\section{Appendix A}

Newspaper Articles (attached as a separate sheet)

\section{Appendix B}

Worldwide cases of Covid-19 infection and mortality rate, as of 24 September 2020.

Cases

Total $\boxplus$ Worldwide

Cases Deaths

32M $978 \mathrm{~K}$

\section{Location Cases Deaths}

\begin{tabular}{|c|c|c|}
\hline 些 & $6.97 \mathrm{M}$ & $202 \mathrm{~K}$ \\
\hline United States & $+41,566$ & $+1,091$ \\
\hline$\odot$ & $5.73 \mathrm{M}$ & 91,149 \\
\hline India & $+86,508$ & $+1,129$ \\
\hline$\theta$ & $4.63 \mathrm{M}$ & $139 \mathrm{~K}$ \\
\hline Brazil & $+33,281$ & +869 \\
\hline & $1.13 \mathrm{M}$ & 19,948 \\
\hline Russia & $+6,595$ & +149 \\
\hline & $784 \mathrm{~K}$ & 24,746 \\
\hline lombia & $+6,731$ & +176 \\
\hline
\end{tabular}

'+' shows new cases reported yesterday · Updated less than 10 mins ago $\cdot$ Sources: Wikipedia and The New York Times. 


\section{Appendix C}

\section{Data Analysis}

Lexical items identified as war metaphors in the given contexts:

combating, confronting, strong foothold, raging, threatening, toll, sacrifices, halt, potential emergency, resilient, make tough decisions, come under the cosh, panic, act irrationally, panic-buying, casualty, front line, high-risk, critical condition, fight the pandemic, shock, resurgence, ravage, collapse, retreat back, intervention, crisis, targeted measures, indiscriminate, grasped, drastically, mitigating the impacts, facing, falls, protection, reinforced

Lexical items identified as metaphors used in the context of Sinophobic writings:

complex and troubling, growing fears, torrid, stemming, verbal attacks, racist antipathy, global conspiracy, disease manufactured

Lexical items identified as metaphors used to allay public fears:

lauds, unlimited budget, devoted, vital, resist the temptation to overdramatize, contingencies, to fuel the recovery, qualitative leap, strengthening, dedicated centers, commitment, pledged, top priority, provide access, exerted, commitments and support

Other lexical items used as metaphors in the discourse on Covid-19 crisis:

debt, repay, warned about a spike, pessimists, structural, highlights, adopted, heading downward, decline, isolationism, protectionism, fractious, gone up, utterly transformed

\section{Copyrights}

Copyright for this article is retained by the author, with first publication rights granted to the journal.

This is an open-access article distributed under the terms and conditions of the Creative Commons Attribution license (http://creativecommons.org/licenses/by/4.0/). 